\title{
The developmental and criminal histories of subgroups of sexual murderers engaging, or not engaging, in post mortem sexual interference, compared to rapists
}

\author{
Tamsin Higgs $^{\mathrm{a}, \mathrm{b}}, *$, Ewa B. Stefanska ${ }^{\mathrm{c}}$, Adam J. Carter ${ }^{\mathrm{d}}$, Kevin D. Browne ${ }^{\mathrm{a}}$ \\ a Centre for Family and Forensic Psychology, Division of Psychiatry and Applied Psychology, School of Medicine, University of Nottingham, United Kingdom \\ b Centre International de Criminologie Comparée, Université de Montréal, Québec, Canada \\ c Department of Psychology, University of Roehampton, London, United Kingdom \\ ${ }^{\mathrm{d}}$ Her Majesty's Prison and Probation Service, London, United Kingdom
}

\section{A R T I C L E I N F O}

\section{Keywords:}

Homicide

Sexual murder

Rape

Necrophilia

Sadism

\begin{abstract}
A B S T R A C T
Purpose: Identifying factors that may predict sexual aggression in the context of directly sexual murder, indirectly sexual murder, and non-fatal outcomes is necessary for advancing a field lacking a substantiated multifactorial theoretical model.

Methods: Eighty-nine sexual murderers engaging in post mortem sexual interference were compared to 92 nonpost mortem sexual interference sexual murderers and 72 rapists on developmental factors, adult lifestyle, and criminal history. An overall model was built using a series of multinomial logistic regression analyses.

Results: Unlike rapists, both groups of sexual murderers experienced a lack of success in sexually intimate relationships. Perpetrators of post mortem sexual interference were rarely necrophiles, but having a history of sadistic behaviors or interests uniquely predicted sexual murder involving post mortem sexual interference. Chronic violent and sexual offending was characteristic of rapists. Psychopathy, measured using the screening version of the Psychopathy Checklist (Hart, Cox, \& Hare, 1995), was not predictive of any outcome.

Conclusion: Results support criticism of existing theoretical models; that they do not apply to non-sadistic sexual murder. Findings are discussed in relation to gaps in theoretical understanding of sexual murder, and concerning implications for forensic policies and practice.
\end{abstract}

\section{Introduction}

Despite a vast amount of popular and academic interest in sexual homicide and what sort of individual is capable of such an act, several researchers have commented on the problematic nature of the subject as far as robust research methodology is concerned. For example, difficulties remain with definition and objective identification criteria, sample selection bias is unavoidable, base rates are low, and researchers face a particular challenge in the reliability and availability of information pertaining to this population (Chan, 2015; Clarke \& Carter, 2000). Recently there have been fruitful efforts to overcome some of these limitations through the identification of larger samples (Beauregard \& Martineau, 2013; Stefanska, Carter, Higgs, Bishopp, \& Beech, 2015), targeting diverse populations such as sexual murderers of men, and female sexual murderers (Beauregard \& Proulx, 2007; Chan \& Frei, 2013; Myers \& Chan, 2012), and inclusion of non- sexual murder control groups (Carter, Hollin, Stefanska, Higgs, \& Bloomfield, 2016). This leads to a position from which it is possible to reach increasingly reliable conclusions about what is known about those who perpetrate such crimes, as well as providing some clarity around those areas demanding further research attention.

Most sexual homicide is perpetrated by men, against women (Chan, Myers, \& Heide, 2010; James \& Proulx, 2014). Although sexual homicide has, more so historically, been conflated with serial killing, the two are not one in the same (Proulx, Cusson, \& Beauregard, 2007). The majority of sexual murderers do not kill repeatedly (Campos \& Cusson, 2007). Maybe they are apprehended before they have further opportunity, but sexual violence recidivism rates appear to be low based on the available post release follow-up data (Hill, Habermann, Klusmann, Berner, \& Briken, 2008; Khachatryan, Heide, Hummel, \& Chan, 2016). Further, there are several psychosocial, criminal career, and modus operandi factors that appear to differentiate between serial and non-

\footnotetext{
* Corresponding author at: Centre International de Criminologie Comparée, Université de Montreal, Pavillon Lionel Groulx, Bureau C4086, C. P. 6128, succursale Centre-Ville, Montréal, Québec H3C 3JC, Canada.

E-mail address: tamsin.wellham@umontreal.ca (T. Higgs).
} 
serial sexual murderers (James \& Proulx, 2014; James \& Proulx, 2016). That said, proposed theories of sexual homicide are generally inattentive to this issue. They also suffer a number of other limitations, first and foremost, they tend to be based on little or no empirical data, or have received only limited scientific validation. The problem of knowledge gaps in theoretical models will be returned to, following a brief review of literature that speaks to heterogeneity among offences categorized as sexual murder. This is important, because some of the limitations in current understanding may be overcome through research designed considering the fact that definitions of sexual murder capture different subtypes.

\subsection{Typologies of sexual murder}

Despite early descriptions of sexual murderers synonymously referring to sadistic murderers (e.g. Brittain, 1970), sexual murder is not necessarily an expression of sexual sadism. There are problems with both conceptual and operational definitions of sexual sadism (Marshall \& Kennedy, 2003), particularly when applied to sexual homicide where it appears to have been used as somewhat of a catch-all term for sadism more or less as first defined: "the experience of sexual, pleasurable sensations (including orgasm) produced by acts of cruelty ... may also consist of an innate desire to humiliate, hurt, wound, or even destroy others" (Krafft-Ebing, 1886, p. 53); erotophonophilia (Money, 1990); or lust murder (Myers, Burgess, Burgess, \& Douglas, 1999). Nevertheless, a subgroup of sexual killers is typically described as sadistic, or less prescriptively, 'deviance driven' (Stefanska et al., 2015). For these perpetrators there is a direct association between killing and sexual arousal (Carter \& Hollin, 2014). Arguably, this is the more salient factor, meaning that although a subgroup of sexual murderers may be typically characterized as sadistic, use of the term as a categorical descriptor may require reflection. Under the label sadistic sexual murder, the key distinction, i.e. the functional significance of the act of killing, is obscured. In that case, rather than being a defining characteristic, sexual sadism represents an important feature common to what may be described as directly sexual murder. This is in line with the findings of a recent systematic review of sexual murder typologies, which proposed the term, sexualized murder to describe the phenomenon (Higgs, Carter, Tully, \& Browne, 2017).

Higgs, Carter, et al. (2017) identified a second type of sexual homicide consistently described in the extant literature, characterized by anger (Beauregard \& Proulx, 2002; Beech, Fisher, \& Ward, 2005; Myers et al., 1999; Stefanska et al., 2015). Perpetrators of these grievancedriven offenses kill in the context of sexual activity, which may or may not be immediately assaultive; often anger precedes or is triggered in a consensual situation (Stefanska et al., 2015). Although some perpetrators may experience sexual arousal associated with the extreme level of violence, typically the link between killing and the sexual element of the offense is indirect.

Finally, some cases meet the broad definition of a sexual murder (minimally, that the victim was found at least partially naked and/or there was evidence of sexual contact; Ressler, Burgess, \& Douglas, 1988) but the sexual element and the act of killing are clearly only indirectly linked. That is, killing is instrumental following a sexual assault (elimination of the witness), or due to violence augmented by victim vulnerabilities, for example.

\subsection{Theoretical models of sexual homicide}

Theoretical hypotheses are offered in the trauma-control model (Hickey, 1997, 2002), and the paraphilic model (Arrigo \& Purcell, 2001), or derived on the basis of preliminary empirical data as in the FBI's motivational model (Burgess, Hartman, Ressler, Douglas, \& McCormack, 1986; Ressler et al., 1988), and Chan, Heide, and Beauregard's (2011) social learning-routine activity integrative model of the offending process in sexual homicide. The common theme within these theoretical models is an emphasis on adverse childhood experiences and the subsequent development of violent sexual fantasies, which are typically considered as the central precipitating factor to sexual homicide.

As such, the existing theoretical models all draw upon theories of social learning (Akers, 1985; Bandura, 1986) and attachment (Ainsworth, 1979), more or less explicitly between authors. In each model, early physical and/or sexual abuse as well as un-nurturing social environments, which fail to provide protection from trauma and foster maladjusted psychosocial development, function as pre-dispositional factors to sexual murder. To some extent, biological factors that may favor sexual aggression are also recognized, as well as operant conditioning that may facilitate the transition from the internal world to the extreme behavior the models seek to explain. However, in some instances there may have been a risk of confirmation bias where possibly unrepresentative samples relied upon displayed similarities to the mostly serial murderer sample of the FBI studies, which is just one possible problem among many difficulties associated with often insufficiently defined and described samples. Also, even the model that was tested on the more representative sample (Chan et al., 2011) was only modestly supported by the data, predicting sexual homicide over non-homicide sexual aggression at around chance level. Moreover, there is no theoretical model of sexual homicide that attempts to explain the different trajectories from pre-dispositional biological and environmental factors and formative events to sexual homicide, which may or may not be driven by sadistic fantasy. For example, there are different pathways to sexual homicide (Stefanska et al., 2015; Vettor, Beech, \& Woodhams, 2014), yet there is no multifactorial theory of sexual homicide that deals with the complexities that begin to be drawn out here. Such a theory would necessarily integrate distal and proximal experiences and processes causally implicated in the offense chain. That is, psychosocial factors linked to onset of offending and criminal career. Further, there has been considerable previous research interest in the role of psychopathy in relation to sexual murder, which requires attention in pursuit of a more complete theory. For example, based on the interpretation of correlations between measures of psychopathy and sadism, some researchers suggest that the motivation for sadistic sexual murder is thrill seeking (Porter, Woodworth, Earle, Drugge, \& Boer, 2003). Others found that sexual sadism and psychopathy have callous lack of empathy as a shared characteristic, but disagree that thrill seeking motivates sadistic behavior (Mokros, Osterheider, Hucker, \& Nitschke, 2011). Proulx and Beauregard (2014) discuss their own and other studies examining the role of psychopathy in sexual aggression, concluding that the debate remains open.

\subsection{Sexual homicide as a subtype of sexual violence}

The question of the distinctiveness of sexual homicide as a discrete type of offending that might require special consideration theoretically and clinically (i.e. for risk assessment and forensic intervention) remains unanswered, in as much as researchers have reported inconclusive or contradictory results (Chan \& Heide, 2009; Kerr, Beech, \& Murphy, 2013). It is difficult to ascertain the extent to which this reflects methodological difficulties including low prevalence rates and sample construction, notably over-representation of serial murderers. Also, many studies examine sexual murderers in isolation, therefore, inferences in relation to what is known about sexual violence more widely are restricted. However, a systematic review addressing the issue found ten articles making direct comparisons between sexual murderers and non-homicide sexual aggressors (Stefanska, Beech, \& Carter, 2016). Overall, sexual murderers were found to experience anger, and especially loneliness to a greater degree than sexual aggressors. The groups appeared similar in several domains: family structure, mental health disorders, and criminal history; whereas it remained unclear whether certain characteristics, including own victimization and psychological factors such as self-esteem, may differ 
between sexual murderers and sexual aggressors (Stefanska et al., 2016). Similar conclusions were drawn by Chan and Heide (2016) in an additional review, although they reported certain characteristics that appeared to distinguish between sexual murderers and non-homicide sexual aggressors such as more problems in childhood and adolescence for the former, and differing criminal event behaviors between groups. However, Chan and Heide (2016) reviewed studies including diverse groups of offenders, such as those with either adult or child victims, whereas Stefanska et al. (2016) limited their review to focus on adult male, non-serial offenders with adult female victims. Discrepant findings are likely related to the different approaches to the review process.

Beauregard, DeLisi, and Hewitt (2017) considered whether sexual murderers are better understood as sex offenders, murderers, or both, based on their criminal careers. They compared sexual murderers to non-homicide sex offenders, distinguishing among the latter those who had perpetrated violently beyond forced sex and those who had not inflicted additional injuries, and found that the violent non-homicide sex offenders had the most varied criminal career, with the highest number of previous convictions relative to the other groups. Sexual murderers were mostly found not to have prior convictions for sexual and violent crimes, but rather a range of other offenses and early onset of criminal career (Beauregard et al., 2017).

However, when making comparisons between sexual murderers and sexual aggressors, typically the heterogeneity within samples of sexual murderers is not taken into account. In the first study to utilize established typologies to minimize the potentially confounding effects of a broad definition of sexual murder when making comparisons to a sample of non-homicide sexual aggressors, Higgs, Carter, Stefanska, and Glorney (2015) specified that research should focus on sexual murder where killing is directly linked to sexual arousal. That is, directly sexual murder/sexualized murder, described above. Thus, their sample included sexual murderers operationalized to include only those engaging in post-mortem sexual interference, in order to exclude all cases where homicide was clearly indirectly sexual. It was found that this operationalization for sampling sexual murderers may provide a useful starting point for further research to reach an improved understanding of this type of crime and those who perpetrate such extreme acts of harm. Further, post mortem sexual interference was one of the few behavioral markers identified by sexual murder typology studies (Higgs, Carter, et al., 2017), supporting the validity of using this as a proxy variable to delineate cases.

\subsection{Current objectives}

Theoretical explanations of sexual homicide require empirical substantiation and there has been a lack of innovation in scientific attention to the problem (DeLisi, 2015). This study aims to address both issues. Specifically, the aims were to examine developmental factors, adult lifestyle, and criminal careers of sexual murderers compared to non-homicide sexual aggressors (rapists).

In line with the hypothesis that the amalgamation of heterogeneous types of sexual murderers attenuates the possibility to detect potential differences between sexual murderers and rapists, sexual murderers were divided into subgroups of those engaging, and those not engaging, in post mortem sexual interference. Post mortem sexual interference was defined to be present when there was disclosure from the perpetrator and/or crime scene or pathology evidence of sexual activity, including sexual mutilation (i.e. of genital areas) but excluding any other post mortem mutilation (i.e. for the purpose of body disposal or destruction of evidence), with an unconscious or dead victim (Carter, Mann, \& Wakeling, 2008; Higgs et al., 2015). That is, cases were included if the victim was assaulted so close to the time of death that despite uncertainty about whether or not the victim was in fact deceased when the sexual assault occurred, there was evidence indicating loss of consciousness. As such, the perpetrator either continued sexual activity with a victim he believed to be dead or dying, or minimally he was not dissuaded by the lifelessness of the victim. This was considered important given that the purpose of operationalization using the presence of post mortem sexual interference was not to study this behavior in itself, but to increase the reliability of samples in terms of whether killing occurred in the context of directly as opposed to indirectly sexual murder. According to this definition, post mortem sexual interference does not necessarily represent a necrophilic subgroup of sexual murderers. Indeed, when these behaviors are attached to murder, typically the motivation is not sexual activity with a corpse (Stein, Schlesinger, \& Pinizzotto, 2010).

Following the argument that population heterogeneity should be considered in the sampling process, the same applies to the comparison sample. Typically, samples of rapists are a combination of violent and non-violent (aside from rape itself being an act of violence) offenders. Yet, a more nuanced understanding comes from comparison research introducing methodological controls for the effects of this amalgamation (Beauregard et al., 2017; Beauregard \& Martineau, 2016). For truly independent samples, the sample of rapists should not contain offenders whose criminal careers would have involved sexual murder given the opportunity. Since some rapists escalate in their offending to commit a sexual murder (Grubin, 1994; Oliver, Beech, Fisher, \& Beckett, 2007), identifying such a sample is impossible. However, the probability that an independent sample has been identified can be improved by restricting the rapists sample to those who may be considered to have offended equally as seriously as the sexual murderers, according to legal categorization. In the UK, indeterminate prison sentences (imprisonment for life or imprisonment for public protection, release being dependent upon Parole Board approval) apply to rape or attempted rape based on the severity of the index offense or a history of serious sexual offending. This legal determination of offense severity provides an objective selection criterion, and is one way to identify a sample of rapists who, arguably, represent the most relevant comparison group in sexual homicide research as opportunity to escalate to sexual murder has been demonstrated.

Given that previous research suggests that the most extreme sexual crimes are a function of more extreme developmental disturbance (Nicole \& Proulx, 2007), and the consistent finding that sexual murderers report loneliness and anger (Stefanska et al., 2016), it was hypothesized that the greatest degree of developmental adversity and lifelong social difficulties would be found among sexual murderers engaging in post mortem sexual interference. Although there are conflicting views in the literature as to whether sexual murderers are specialized in their offending or career criminals, overall previous research indicated that it may be hypothesized that there would be evidence of habitual or chronic offending in all three groups (DeLisi, 2015). However, psychopathy was hypothesized to predict non-post mortem interference sexual murder, and rape, over post mortem interference sexual murder. This is in line with previous characterizations of sexual murderers; the sadistic type, more akin to the current post mortem interference sample insofar as these should be directly sexual murders; compared to the non-post mortem interference sample, which may contain a greater proportion of opportunistic offenders, who are more likely psychopathic (Proulx \& Beauregard, 2009).

\section{Method}

\subsection{Design}

The study was descriptive and comparative in design. Data was obtained from the Public Production Unit Database (PPUD), which stores Her Majesty's Prison and Probation Service (HMPPS) records relating to all prisoners detained in England and Wales. The records accessed included pre- and post-sentence psychiatric and probation reports, official criminal records, and prison file information such as psychological assessments and multidisciplinary reports prepared for parole hearings and so forth. The study aimed to explore whether 
specific developmental factors and criminal trajectories are related to the type of the offender's last crime (sexual murder involving post mortem sexual interference, sexual murder without post mortem sexual interference, or non-homicide sexual aggression, i.e., rape).

\subsection{Sample}

The sample used in the present study comprised 253 males, all of whom had received an indeterminate prison sentence (imprisonment for life or imprisonment for public protection, release in both cases requiring approval from the Parole Board). For inclusion in the study, all index offenses must have been perpetrated when the offender was aged at least 18 years (for the purpose of the study 'index offense' refers to the sexual murder or rape/attempted rape resulting in an indeterminate sentence). Victims of the index offense were female, aged 14 years or over. Murderers were non-serial (one or two victims with no emotional cool-off period, that is, apparently a single event; Proulx et al., 2007).

The first stage of the sampling strategy required a search of HMPPS databases, which identified 916 offenders with a conviction for murder or manslaughter, meeting the above criteria, whose offenses were recorded as involving a sexual element and/or sexual motivation that was evidenced, suspected, or admitted. Despite the legal connotations of the terminology, for simplicity this group will be referred to as sexual murderers herein. A preliminary review of files yielded 350 cases of sexual murder, after exclusion of those where information was substantially or entirely missing, or the initial search had produced false positives (i.e., not all of the study inclusion criteria were met). From this preliminary file review it was also established whether or not the perpetrator had engaged in post-mortem sexual interference (as defined above), giving a final sample of sexual murderers who had engaged in post-mortem sexual interference (or, post-mortem sexual interference sexual murderers; PMSI sexual murderers) comprising 89 cases.

The sample of sexual murderers who had not engaged in postmortem sexual interference (non-PMSI sexual murderers) included 92 cases quasi-randomly selected from the remainder of those identified during the initial screening. For each post-mortem sexual interference case, the next individual appearing in the database was included in the study. Likewise, rapists were identified from HMPPS databases and a sample of 72 cases was similarly quasi-randomly selected.

All offenders included in the study were born between 1932 and 1989; PMSI sexual murderers, $M=1959$; non-PMSI sexual murderers, $M=1962$; rapists, $M=1962$. The ethnicity of the samples was mostly White British; 91\% $(n=81), 82.6 \%(n=76)$, and $77.8 \%(n=56)$ for PMSI sexual murderers, non-PMSI sexual murders, and rapists, respectively. The remainder of the sample of PMSI sexual murderers was Black (Caribbean, African, or other Black background; $4.5 \%, n=4$ ), or other ethnicity (non-British White backgrounds, Mixed, Asian, or no ethnicity recorded; $4.5 \%, n=4$ ). The remainder of the sample of nonPMSI sexual murderer was Black; $4.3 \%(n=4)$, or other ethnicity; $13 \%$ $(n=12)$. The remainder of the sample of rapists were Black; $15.3 \%$ $(n=11)$, or other ethnicity; $6.9 \%(n=5)$.

\subsection{Procedure and measures}

Developmental and adult lifestyle information and criminal career details were collated from PPUD. Evidence for each variable was scored dichotomously (present or absent), or numerically (such as frequency of offense types), and managed within a coding framework developed on the basis of previous research (James \& Proulx, 2014). Coding adhered to pre-defined operationalization of each item. Although these operationalizations may not feasibly be reported in full, noteworthy items are: major mental illness and personality disorders, which required formal diagnosis retrieved from files (evidence within psychiatric and psychological reports at trait-level only were not considered sufficient to code for the presence of personality disorder); paraphilias, which required either retrieval of formal diagnosis, or file evidence consistent with DSM-5 (American Psychiatric Association, 2013) criteria; promiscuity, which was coded on the basis of reports describing frequent casual sex or self-report of at least fifteen sexual partners (Proulx, 2014); and long-term co-habiting relationships, which meant at least two years (Thornton, 2007). The first $10 \%$ of cases were double coded, with good strength of agreement (Cohen's $\kappa=0.81$ ).

Each case was also assessed for psychopathy using the Psychopathy Checklist: Screening Version (PCL: SV; Hart et al., 1995). Psychometric properties obtained from forensic samples support the use of this measure for research purposes (Higgs, Tully, \& Browne, 2017). However, to assess convergent validity in the present sample, where full Psychopathy Checklist-Revised (PCL-R; Hare, 2004) assessment reports were found within PPUD, these were accessed after all other information was collated and PCL: SV items scored, and total PCL-R scores were recorded. A Pearson product-moment correlation was run to determine the relationship between PCL-R and PCL: SV scores. The data showed no violation of normality, linearity or homoscedasticity. There was a strong, positive correlation between scores on the two measures ( $r=0.86, n=103, p<0.001)$. Therefore, PCL: SV scores were relied upon for between group comparisons.

\subsection{Analytical strategy}

Variables were organized into three categories pertaining to developmental factors, adult lifestyle, and criminal career. Most variables were dichotomous (present or absent). However, aggregated signs of disturbance in particular areas should relate to adult offending severity more so than the presence or absence of individual factors (Hickey, 2002; Nicole \& Proulx, 2007). Therefore, it was theoretically preferable to combine variables in related areas. Following this theory-driven approach, where possible variables were grouped according to type of disturbance or difficulty, and sum totals of the individual variables were calculated. This effectively created three scales: a Detrimental Model Exposure Scale comprising items relating to exposure to violence against women, inappropriate parental sexual behavior, and substance abuse (witnessing domestic violence, sexual violence, psychological harm to others, mother's prostitution or promiscuity, and parental substance abuse); a Negative Childhood Experiences Scale comprising victimization items (physical, sexual, and psychological abuse, and neglect); and a Developmental Inadequacies Scale comprising of indicators of behavioral maladaptation in childhood (referral to child psychiatrist/psychologist, truancy, cruelty to animals, social isolation, enuresis, anxiety disorder, running away from home, self-harm, substance abuse, fire-setting, violence towards others). To test the validity of the scales, confirmatory factor analysis was completed, in MPlus (v5.21; Muthén \& Muthén, 2007). The Detrimental Model Exposure scale had too many items with insufficient frequencies for the analysis to be performed and was therefore rejected with the items being reverted back to dichotomous variables. Low frequency items and those that were too strongly correlated were removed from the two remaining scales, and correlated errors were accepted where particular relationships between variables were theoretically likely (namely, social isolation and anxiety, and social isolation and enuresis). The fit indices for the Negative Childhood Experiences Scale were acceptable, Comparative Fit Index $(\mathrm{CFI})=1.00$, Tucker Lewis Index $(\mathrm{TLI})=1.012$, Root Mean Square Error of Approximation (RMSEA) $=0.00, \chi^{2} \quad(2$, $N=249)=1.65, p=0.44$. Reliability based on tetrachoric correlations was good (alpha $=0.74$ ). For the Developmental Inadequacy Scale, fit indices were also acceptable, CFI $=0.912$, TLI $=0.902$, RMSEA $=0.045, \chi^{2}(27, N=249)=40.53, p=0.05$, as was reliability (alpha $=0.78$ ).

Chi-square tests for independence and one-way ANOVA (or KruskalWallis Tests where appropriate) were then carried out, and variables were selected for multivariate analysis using a threshold of $p<0.25$ (Hosmer \& Lemeshow, 2000). Those variables falling below this 
Table 1

Developmental and adult lifestyle factors present for post mortem sexual interference sexual murderers (PMSI sexual murderers), non-post mortem interference sexual murderers (nonPMSI sexual murderers), and rapists.

\begin{tabular}{|c|c|c|c|c|c|}
\hline & PMSI sexual murderers $(n=89)$ & Non-PMSI sexual murderers $(n=92)$ & Rapists $(n=72)$ & \multirow[b]{2}{*}{$\chi^{2}$} & \multirow[b]{2}{*}{$p$} \\
\hline & $\%$ & & & & \\
\hline Only child ${ }^{\mathrm{a}}$ & 9 & 4 & 3 & 3.24 & 0.20 \\
\hline Youngest child & 28 & 25 & 25 & 0.21 & 0.90 \\
\hline Eldest child & 27 & 28 & 35 & 1.27 & 0.53 \\
\hline Large family & 51 & 57 & 66 & 3.37 & 0.19 \\
\hline Parent psychiatric history ${ }^{\mathrm{a}}$ & 11 & 5 & 3 & 4.92 & 0.09 \\
\hline Parent substance misuse & 25 & 27 & 22 & 0.53 & 0.77 \\
\hline Domestic violence & 24 & 27 & 32 & 1.34 & 0.50 \\
\hline Sexual domestic violence ${ }^{\mathrm{a}}$ & 6 & 4 & 7 & 0.52 & 0.77 \\
\hline Witness psychological abuse ${ }^{a}$ & 2 & 5 & 4 & 1.22 & 0.54 \\
\hline Promiscuous mother ${ }^{\mathrm{a}}$ & 3 & 3 & 8 & 2.87 & 0.24 \\
\hline Parent criminal history & 14 & 10 & 7 & 1.88 & 0.39 \\
\hline Parent violent crime $^{\mathrm{a}}$ & 2 & 5 & 0 & 4.36 & 0.11 \\
\hline Parent sexual crime $\mathrm{a}^{\mathrm{a}}$ & 2 & 2 & 2 & 0.14 & 0.93 \\
\hline Parent other crime ${ }^{\mathrm{a}}$ & 8 & 4 & 2 & 3.58 & 0.17 \\
\hline Sibling criminality & 12 & 21 & 17 & 2.25 & 0.33 \\
\hline Grew up with biological parents & 48 & 44 & 46 & 0.43 & 0.81 \\
\hline Single mother & 14 & 14 & 14 & 0.02 & 0.99 \\
\hline Grew up with step-parent & 17 & 23 & 14 & 2.33 & 0.31 \\
\hline Grew up with grandparents ${ }^{a}$ & 7 & 1 & 1 & 4.16 & 0.13 \\
\hline Disrupted caregiving & 8 & 14 & 10 & 1.96 & 0.38 \\
\hline Taken into public care & 38 & 37 & 35 & 0.21 & 0.90 \\
\hline Death of parent(s) & 18 & 13 & 11 & 1.70 & 0.43 \\
\hline Felt rejected by family ${ }^{\mathrm{a}}$ & 6 & 10 & 8 & 1.10 & 0.58 \\
\hline Parental lack of emotional warmth & 14 & 11 & 14 & 0.47 & 0.79 \\
\hline Family scapegoat $^{\mathrm{a}}$ & 7 & 2 & 3 & 3.10 & 0.21 \\
\hline Domineering mother ${ }^{\mathrm{a}}$ & 9 & 7 & 6 & 0.96 & 0.62 \\
\hline Anger towards mother ${ }^{\mathrm{a}}$ & 3 & 1 & 4 & 1.61 & 0.45 \\
\hline Failure to meet high standards ${ }^{\mathrm{a}}$ & 1 & 2 & 3 & 0.59 & 0.74 \\
\hline Parents frequent arguing ${ }^{\mathrm{a}}$ & 0 & 2 & 0 & 3.53 & 0.17 \\
\hline Traumatic experience & 18 & 12 & 14 & 1.36 & 0.51 \\
\hline Victim of bullying & 45 & 41 & 42 & 0.29 & 0.87 \\
\hline Sexual development problems $\mathrm{s}^{\mathrm{a}}$ & 0 & 1 & 1 & 1.14 & 0.57 \\
\hline Sexual aggression $<18$ & 21 & 17 & 25 & 1.43 & 0.49 \\
\hline Antisocial behavior $<18$ & 53 & 64 & 65 & 3.40 & 0.18 \\
\hline Diagnosed conduct disorder ${ }^{a}$ & 2 & 0 & 0 & 3.72 & 0.17 \\
\hline Learning disability & 10 & 13 & 18 & 2.18 & 0.34 \\
\hline Left school without qualification & 60 & 58 & 61 & 0.21 & 0.90 \\
\hline Employment problems & 64 & 57 & 51 & 2.63 & 0.27 \\
\hline Alcohol misuse & 57 & 47 & 44 & 2.96 & 0.23 \\
\hline Drug use & 46 & 41 & 56 & 3.34 & 0.19 \\
\hline Cannabis & 40 & 34 & 50 & 4.23 & 0.12 \\
\hline Depressants (not cannabis) & 15 & 12 & 17 & 0.70 & 0.71 \\
\hline Stimulants & 27 & 26 & 41 & 5.42 & 0.07 \\
\hline Hallucinogens & 19 & 12 & 19 & 2.15 & 0.34 \\
\hline Head injury & 15 & 15 & 10 & 1.21 & 0.55 \\
\hline Adult social isolation & 63 & 49 & 44 & 6.23 & 0.04 \\
\hline Sexual inexperience & 18 & 13 & 6 & 5.58 & 0.06 \\
\hline Never had intimate partner ${ }^{\mathrm{a}}$ & 11 & 10 & 1 & 6.07 & 0.05 \\
\hline Never long-term co-habiting partner & 70 & 62 & 33 & 23.11 & $<0.001$ \\
\hline Promiscuity & 33 & 37 & 60 & 13.49 & $<0.01$ \\
\hline Sexual contact with sex workers & 7 & 8 & 33 & 28.24 & $<0.001$ \\
\hline Self-prostitution ${ }^{\mathrm{a}}$ & 6 & 3 & 4 & 0.61 & 0.74 \\
\hline Sexual dysfunction ${ }^{\mathrm{a}}$ & 9 & 4 & 8 & 1.70 & 0.43 \\
\hline Paraphilia & 38 & 15 & 28 & 12.20 & 0.00 \\
\hline Fetishism $^{\text {a }}$ & 7 & 5 & 4 & 0.51 & 0.78 \\
\hline Frotteurism ${ }^{a}$ & 0 & 0 & 1 & 2.52 & 0.28 \\
\hline Pedophilia $^{\mathrm{a}}$ & 1 & 0 & 1 & 1.19 & 0.55 \\
\hline Exhibitionism $^{\mathrm{a}}$ & 5 & 9 & 8 & 1.43 & 0.49 \\
\hline Sexual masochism ${ }^{\mathrm{a}}$ & 2 & 1 & 4 & 1.66 & 0.44 \\
\hline Transvestitism ${ }^{\mathrm{a}}$ & 1 & 1 & 0 & 0.80 & 0.67 \\
\hline Voyeurism $^{\mathrm{a}}$ & 5 & 4 & 7 & 0.68 & 0.71 \\
\hline Necrophilia $^{a}$ & 5 & 0 & 0 & 7.49 & 0.02 \\
\hline Telephone scatophilia $^{\mathrm{a}}$ & 0 & 3 & 6 & 4.70 & 0.10 \\
\hline Bestiality $^{\mathrm{a}}$ & 1 & 0 & 0 & 1.85 & 0.40 \\
\hline Sexual sadism & 24 & 1 & 8 & 24.05 & 0.00 \\
\hline Disclosed rape fantasies & 22 & 17 & 29 & 3.27 & 0.20 \\
\hline Major mental disorder & 10 & 10 & 11 & 0.08 & 0.96 \\
\hline Personality disorder & 15 & 16 & 11 & 0.91 & 0.64 \\
\hline Autism Spectrum Disorder ${ }^{a}$ & 1 & 2 & 0 & 1.63 & 0.44 \\
\hline Homelessness & 9 & 11 & 17 & 2.38 & 0.30 \\
\hline
\end{tabular}

${ }^{a}$ Excluded from further analysis as observed frequency $<10 \%$. 
Table 2

Criminal histories of post mortem sexual interference sexual murderers (PMSI sexual murderers), non-post mortem interference sexual murderers (non-PMSI sexual murderers), and rapists.

\begin{tabular}{|c|c|c|c|c|c|c|c|c|}
\hline & \multicolumn{2}{|c|}{ PMSI sexual murderers } & \multicolumn{2}{|c|}{ Non-PMSI sexual murderers } & \multicolumn{2}{|c|}{ Rapists } & \multirow[b]{2}{*}{$F$ or $\chi^{2}$} & \multirow[b]{2}{*}{$p$} \\
\hline & $M$ & $S D$ & $M$ & $S D$ & $M$ & $S D$ & & \\
\hline Age at first conviction & 18.40 & 5.50 & 17.23 & 6.08 & 19.75 & 10.14 & 3.99 & 0.14 \\
\hline Previous violent offenses & 1.33 & 2.04 & 2.24 & 3.49 & 4.24 & 6.26 & 23.43 & 0.00 \\
\hline Age at first violent conviction & 19.24 & 5.35 & 18.40 & 4.32 & 21.75 & 6.87 & 8.35 & 0.02 \\
\hline Previous sexual offenses & 0.38 & 0.83 & 0.83 & 1.67 & 2.58 & 5.12 & 27.19 & 0.00 \\
\hline Previous rape/attempted rape & 0.10 & 0.30 & 0.20 & 0.60 & 0.54 & 0.90 & 22.14 & 0.00 \\
\hline Sexual offenses against children & 0.12 & 0.50 & 0.13 & 0.62 & 0.25 & 0.78 & 0.71 & 0.71 \\
\hline Age at first sexual conviction & 20.70 & 5.29 & 20.83 & 6.44 & 23.07 & 6.72 & 2.45 & 0.29 \\
\hline Non-violent non-sexual offenses & 12.07 & 19.89 & 20.98 & 33.87 & 29.86 & 50.68 & 12.79 & 0.00 \\
\hline Age first non-violent non-sex conviction & 16.61 & 3.53 & 15.81 & 4.13 & 17.84 & 6.72 & 3.58 & 0.17 \\
\hline Age at time of index offense & 26.64 & 6.96 & 26.42 & 8.01 & 39.03 & 8.66 & 64.98 & 0.00 \\
\hline \multirow[t]{2}{*}{ Age of index offense victim } & 33.85 & 19.16 & 35.36 & 22.29 & 31.76 & 17.83 & 0.64 & 0.53 \\
\hline & $\%$ & & & & & & $\chi^{2}$ & $p$ \\
\hline History of alleged sexual violence & 27 & & 27 & & 38 & & 2.67 & 0.26 \\
\hline Previous sex offense with male victim & 5 & & 1 & & 1 & & 2.69 & 0.26 \\
\hline Previous offending includes burglary & 39 & & 36 & & 43 & & 0.88 & 0.65 \\
\hline Has no prior convictions & 17 & & 14 & & 8 & & 2.54 & 0.28 \\
\hline
\end{tabular}

significance level were disregarded at this stage, as were low frequency ( $<10 \%$ prevalence) variables. Remaining variables were tested using multinomial logistic regression, in three blocks (developmental factors, adult lifestyle, and criminal career). A final model was derived based on the outcome of analyses of the three blocks. PMSI sexual murderers were selected as the reference group, in accordance with the research hypotheses.

\section{Results}

Non-significant differences were found between groups on several developmental, adult lifestyle, and criminal career factors (Tables 1 and 2). As such, the bivariate analyses precluded several of the dichotomous variables as candidates for the multivariate model. Likewise, the Negative Childhood Experiences Scale was excluded from further analysis because a Kruskal-Wallis $\mathrm{H}$ test found non-significant differences between rapists, PMSI sexual murderers, and non-PMSI sexual murderers, $\chi^{2}(2, N=253)=0.42, p=0.42$. A one-way ANOVA showed that there was a statistically significant difference between groups on the Developmental Inadequacies Scale, $F(2,252)=4.19, p=0.02$. Posthoc comparisons using the Sidak test found that the mean score for PMSI sexual murderers $(M=2.93, S D=2.19)$ was significantly higher than for rapists $(M=2.06, S D=1.70)$. Non-PMSI sexual murderers $(M=2.63, S D=1.81)$ did not differ significantly from either PMSI sexual murderers or rapists.

No difference in psychopathy was found between groups. Scores on the PCL: SV were not significantly different between PMSI sexual murderers $(M=11.54, S D=5.10)$, non-PMSI sexual murderers $(M=11.29, S D=5.06)$, or rapists $(M=11.57, S D=4.53): F(2,250)$ $=0.08, p=0.92$.

Main effects method multinomial logistic regression analyses were performed to assess prediction of membership in the three categories of outcome (PMSI sexual murderers, non-PMSI sexual murderers, and rapists). First, on the basis of developmental, adult lifestyle, and criminal career predictors and then to assess the improvement in the model taking the strongest predictors $(p<0.05)$ from each of these blocks within an overall model. Developmental predictors were growing up within a large family, antisocial behavior, and maladaptive behavior measured by the Developmental Inadequacy Scale. Adult lifestyle predictors were alcohol misuse, using cannabis, using stimulants, social isolation, sexual inexperience, never having had a co-habiting relationship lasting two years or more, sexual contact with sex workers, promiscuity, sadistic interests or behavior, and disclosure of rape fantasies. Criminal career predictors were age at first conviction for any offense, frequency of previous violent offenses, age at first conviction for a violent offense, frequency of previous sexual offenses, frequency of previous convictions for rape or attempted rape, frequency of nonviolent non-sexual offenses, and age at first non-violent non-sexual offense.

No predictors were included where violation of linearity of the logit was observed. Evaluation of adequacy of expected frequencies for categorical predictors revealed no need to restrict tests of the model. There was good model fit (discrimination among groups) for each of the three blocks using a deviance criterion, $\chi^{2}(54, N=253)=58.57$, $p=0.31$ for the developmental block, $\chi^{2}(240, N=253)=238.93$, $p=0.51$ for the adult lifestyle block, and $\chi^{2}(268, N=253)=255.77$, $p=0.69$ for the criminal career block. In the final model, deviance was also acceptable, $\chi^{2}(368, N=253)=345.43, p=0.80$, Nagelkerke $R^{2}=0.40$.

Classification was unimpressive for the developmental block (44\% overall correct classification rate), the adult lifestyle block (53\% overall), and the criminal career block (51\% overall), but slightly improved in the overall model where correct classification rates were $51 \%$ for PMSI sexual murderers, $63 \%$ for non-PMSI sexual murderers, and $54 \%$ for rapists, with an overall correct classification rate of $56 \%$.

In the developmental block, antisocial behavior and Developmental Inadequacy Scale scores predicted group membership. Antisocial behavior in childhood and adolescence was less frequent among PMSIsexual murderers than non-PMSI sexual murderers and rapists. Problems with developmental inadequacy were not statistically significantly different between PMSI sexual murderers and non-PMSI sexual murderers, but PMSI sexual murderers had statistically significantly higher scores on the Developmental Inadequacy Scale than rapists. With a one point increase on the Developmental Inadequacy Scale, the odds of being in the rapist sample would be expected to decrease by a factor of 0.68 assuming other variables in the model are held constant. This indicates that rapists were less likely than PMSI sexual murderers to have had socialization and anxiety difficulties in childhood, expressed in behaviors such as self-harm, fire-setting, cruelty to animals, and substance abuse.

On factors present in adulthood, non-sadists relative to sadists were more likely to be in the non-PMSI sexual murderers or rapists groups; the odds of being in the non-PMSI sexual murders group as opposed to the PMSI sexual murderers decreased by a factor of 0.03 with the presence of sadism when other variables in the model are held constant, and the odds of being in the rapists group as opposed to the PMSI sexual murderers group decreased by a factor of 0.23 with the presence of sadism when other variables in the model are held constant. Differences 
were also found in the sexual lifestyles of PMSI sexual murderers and rapists (but not between PMSI sexual murderers and non-PMSI sexual murderers). The odds of being in the rapists group as opposed to the PMSI sexual murderers group was 5 times greater where evidence of having had sexual contact with sex workers was found, whereas never having had a co-habiting relationship lasting at least two years decreased the odds of being in the rapists group rather than the PMSI sexual murderers group by a factor of 0.27 . That is, rapists were more likely than PMSI sexual murderers to have had sexual contact with prostitutes, and rapists were more likely to have experienced long term relationships.

Rapists had been convicted more frequently than PMSI sexual murderers for both violent and sexual offenses. The odds of being in the rapists sample rather than the PMSI sexual murderers sample increased by a factor of 1.24 for each additional violent offense with other variables held constant, and was 1.5 times greater with an additional sexual offense with other variables held constant.

In the final model, the three groups were distinguished on the basis of six predictors overall: developmental inadequacy, sexual contact with sex workers, absence of long-term co-habiting relationships, violent and sexual offending, and sadism (Table 3). Sadistic interests or behaviors were most common among PMSI sexual murderers and least common among Non-PMSI sexual murderers. The greatest numbers of both violent and sexual offenses were found among rapists and the lowest frequency of violent and sexual offending was among PMSI sexual murderers. Sexual lifestyles involving sexual contact with sex workers, and having long-term relationships, were most common among rapists whereas PMSI sexual murderers were most likely to have experienced a lack of intimacy, which although not a statistically significant predictor, in the extreme meant a total absence of consensual sexual experience.

\section{Discussion}

New perspectives on life course factors antecedent to serious sexual aggression are gained when within-group heterogeneity is reflected methodologically in the comparison of sexual murderers and rapists. That is, via sampling strategies developed on the basis of previous research. In this study three groups were compared: Sexual murderers engaging in post mortem sexual interference, for whom there is a direct association between killing and sexual arousal; sexual murderers not

Table 3

Multinomial logistic regression model of antecedent factors for sexual aggressors: NonPMSI sexual murderers and rapists versus PMSI sexual murderers.

\begin{tabular}{|c|c|c|c|}
\hline & \multirow{2}{*}{$\frac{\text { Odds }}{\text { Ratio }}$} & \multicolumn{2}{|c|}{ 95\% C.I. for Odds Ratio } \\
\hline & & Lower & Upper \\
\hline \multicolumn{4}{|l|}{ Non-PMSI sexual murderers } \\
\hline Antisocial behavior $<18$ & 1.55 & 0.75 & 3.20 \\
\hline Developmental inadequacy & 0.95 & 0.79 & 1.15 \\
\hline Sadism ${ }^{* *}$ & 0.04 & 0.01 & 0.29 \\
\hline Sexual contact with sex workers & 0.99 & 0.29 & 3.36 \\
\hline Never long-term co-habiting partner & 0.69 & 0.34 & 1.39 \\
\hline Previous violent offenses & 1.11 & 0.97 & 1.27 \\
\hline Previous sexual offenses & 1.24 & 0.94 & 1.65 \\
\hline \multicolumn{4}{|l|}{ Rapists } \\
\hline Antisocial behavior $<18$ & 1.60 & 0.68 & 3.78 \\
\hline Developmental inadequacy* & 0.76 & 0.59 & 0.98 \\
\hline Sadism & 0.46 & 0.14 & 1.49 \\
\hline Sexual contact with sex workers ${ }^{*}$ & 4.02 & 1.32 & 12.30 \\
\hline Never long-term co-habiting partner ${ }^{* *}$ & 0.29 & 0.13 & 0.64 \\
\hline Previous violent offenses ${ }^{* *}$ & 1.24 & 1.08 & 1.42 \\
\hline Previous sexual offenses ${ }^{* *}$ & 1.54 & 1.16 & 2.04 \\
\hline
\end{tabular}

Note: $\mathrm{R}^{2}=0.35$ (Cox \& Snell), 0.40 (Nagelkerke). Model $\chi^{2}=110.36, p<0.001$.

${ }^{*} p<0.05$.

${ }^{* * *} p<0.01$ engaging in post mortem sexual interference, a sample more representative of indirectly sexual murder; and rapists who had received a life or indeterminate sentence.

Results of the present study indicated that childhood adversity was typical among all three groups of offenders sampled; victimization and trauma was found similarly among PMSI sexual murderers, non-PMSI sexual murderers, and rapists. This was inconsistent with the hypothesis that PMSI sexual murderers would have experienced the most disturbance early in life. However, the results indicated that the groups differed on their behavioral responses and trajectories through their criminal careers. This suggests that victimization and trauma insufficiently explains predisposition to sexual murder. Indeed, such experiences are a common feature of general theories of sexual offending (e.g. Ward \& Beech, 2006), the implication being that the processes resulting in sexual murder as opposed to non-homicide sexual aggression are inadequately understood. Present findings suggest that internalization of harmful experiences differentially predicts eventual offense severity.

These different processes transpired in the behavioral characteristics of the three samples. A key feature of PMSI sexual murderers was developmental inadequacy. They were socially isolated from childhood, and were more likely to have adopted maladjusted coping behaviors such as self-harm, fire-setting, and hostility to others expressed through aggressive behavior towards peers and adults, and cruelty to animals. Previous research has suggested that sexual murderers are likely to report persistently low self-esteem (Healey \& Beauregard, 2015), and emotional loneliness has been consistently identified as characteristic (Grubin, 1994; Higgs et al., 2015; Milsom, Beech, \& Webster, 2003; Nicole \& Proulx, 2007). Concordantly, present results suggested that reaching adulthood, PMSI sexual murderers were unable to improve their social circumstances and they were unsuccessful in sexual relationships. Often they were sexually inexperienced, in some cases never having had a consensual sexual partner. Perhaps as a way to cope with this lack of intimacy, they developed deviant sexual fantasies that would play a central role precipitating their offense (Maniglio, 2010). The few empirical studies of necrophilia (noting that both in the present study, and in previous research, post mortem sexual interference following homicide rarely indicates presence of paraphilia according to diagnostic criteria, e.g. other specified paraphilic disorder - necrophilia; DSM-V, American Psychiatric Association, 2013), offer two main hypotheses: A perpetrator who is fearful of rejection by women seeks an unresisting partner, or murder itself failed to satisfy the desire to act out deviant fantasies (Rosman \& Resnick, 1989; Stein et al., 2010). Both inferences are consistent with the profile of an individual unable to achieve fulfilling intimate relationships, resorting to sadistic fantasies to overcome emotional loneliness and resentment towards women. Further, these men develop sexual entitlement beliefs (Higgs et al., 2015), fuelling their propensity towards sexual murder when their sexual needs are unmet.

The question of crime-specialization among sexual murderers requires further research. The extant literature on this issue offers differing conceptualizations of subgroups of offenders depending on sample bias (Harris, Knight, Smallbone, \& Dennison, 2011), and no study has examined versatility versus specialization for subtypes of sexual murderers. Present findings suggest that the criminal careers specific to subtypes of sexual murderers differ, with a notable low frequency of prior violent and sexual crimes among PMSI sexual murderers. However, although PMSI sexual murderers had offended less frequently overall, including general offending, than either non-PMSI sexual murderers or rapists, they still appeared to be habitual offenders (based on total previous offenses, although the present study did not detail number of arrests, necessary to evaluate chronicity; DeLisi, 2015). At the point of criminal investigation, such information indicates that recommendations to direct resources towards identification of suspects with previous sexual convictions are likely to be erroneous (Beauregard et al., 2017). Present findings suggest that this might be an 
especially imperative warning in cases where it may be suspected that killing was directly associated with sexual arousal, based on evidence such as indicators of post mortem sexual interference.

In contrast, rapists were less likely to have developed socialization and anxiety difficulties as children. However, although statistically nonsignificant, rapists experienced the most exposure to detrimental models (based on bivariate analysis of variables pertaining to witnessing violence or inappropriate sexual behavior in the home). This provides some support for applying social learning theory to understanding different manifestations of sexual violence. For rapists in this study, exposure to victimization of women, or in some cases witnessing their mother's infidelity or involvement in prostitution, may be hypothesized as important factors in the development of implicit theories favoring sexual aggression (Beech et al., 2005), which may not necessarily result in fatal injury, depending on situational factors (Beauregard \& Mieczkowski, 2012). In adulthood, rapists in this study were sexually promiscuous, engaging in long term and casual relationships and having sexual contact with prostitutes. Their criminal careers typically involved a high frequency of all types of sexual, violent, and acquisitive or general offending. Psychopathy was not predictive of any outcome. However, the rapists' more pervasive criminal histories stemmed from a pattern of antisocial behavior beginning in childhood, suggesting that for this sample of rapists, sexual offending occurs as part of a polymorphic antisocial lifestyle (Proulx \& Beauregard, 2009). Interestingly, antisocial behavior in childhood was very nearly as commonly found among non-PMSI sexual murderers as rapists, and subsequently, the criminal careers of nonPMSI sexual murderers comprised less of all types of offending than rapists, but more than PMSI sexual murderers. As such, non-PMSI sexual murderers and rapists appear to represent a more antisocial, if not psychopathic, type of offender than PMSI sexual murderers, who are motivated to act upon their fantasies (Beech et al., 2005), or compulsion (Revitch \& Schlesinger, 1989).

Perhaps unsurprisingly, non-PMSI sexual murderers appeared to represent somewhat of a mixed group, sharing some similarities with PMSI sexual murderers, such as experiencing developmental inadequacy and subsequently having unsuccessful sexual relationships in adulthood, while their early criminal careers included violent offenses but still less frequent sexual crimes than rapists. Present findings support the hypothesis that the amalgamation of subtypes of sexual murderers into a single group by comparison to rapists attenuates potential differences between groups. As has been argued elsewhere (Stefanska et al., 2015), when sex is indirectly associated to homicide, as in the majority of non-PMSI sexual murders, perpetrators may be more akin to rapists than sexual murderers driven by deviancy (directly sexual murder). That is, a conceptualization of a continuum of sexual aggression culminating in sexual murder depending on circumstantial violence (Oliver et al., 2007; Proulx et al., 2007; Salfati \& Taylor, 2006) appears to account well for indirectly sexual murders but perhaps less so for directly sexual murders. The present results are in line with the suggestion that direct cases need to be reliably identified and theoretical models are needed that account for this distinction. Psychological theory of criminal behavior is fundamental to forensic intervention (Andrews, 1995), and validation studies have not been conducted for assessment tools used, but not specifically developed for, this population (Clarke \& Carter, 2000; Hill et al., 2012; Tardif, Dassylva, \& Nicole, 2007). As such, moving towards an empirically supported understanding of sexual murder has important implications for policy and practice.

\subsection{Limitations and future directions}

The present study represents one of the largest-scale studies of sexual homicide conducted to date, in that previous research focusing on similar variables has without exception relied upon much smaller samples, or no empirical data at all. The necessary compromise was a reliance on file information unaccompanied by interview material. Files were comprehensive, but reporting practices evolving over time meant that there was some case-to-case inconsistency in the quality of information. As such, there were limitations in data extraction in some areas. Particularly, the prevalence of personality disorders is likely to be underestimated in the present study because only recorded diagnoses were considered as acceptable evidence, whereas frequently psychiatric and psychological assessments reported traits indicative of disorder, but stopped short of reaching a diagnostic conclusion. Although the present study did not consider maladaptive personality at the trait level, other researchers have found that sexual murderers more frequently exhibit paranoid, schizotypal, borderline, histrionic, narcissistic, obsessivecompulsive, impulsive, and odd or eccentric traits than rapists (Chan \& Beauregard, 2016). It may be worthwhile for future research to examine whether these tendencies bear out for directly and indirectly sexual murderers, or whether the latter may present with personality functioning more similar to rapists. Similarly, the role of specific criminological factors among different types of sexual aggressors needs to be better understood. For example, Healey and Beauregard (2017) questioned why it might be that impulsivity was predictive of sexual murder rather than non-homicidal sexual aggression in their sample, while they also observed premeditation among sexual murderers. One hypothesis offered was that a subgroup of sexual murderers intended to kill irrespective of any situational factors shaping the actual course of the criminal event (Healey \& Beauregard, 2017). Plausibly, cases of directly sexual murder may have been premeditated, whereas the finding that impulsivity was predictive of fatal outcomes may be explained by its role in indirectly sexual murder.

A final comment is necessary on the novel operationalization of both sexual murderer samples and rapists used in this study. While it is argued that this approach allows for advances to be made in understanding serious sexual violence, sampling is not consistent with the majority of the research literature meaning that contradictions with previous research must be carefully evaluated. Most importantly, post mortem sexual interference was used as a proxy for identifying directly sexual murders. Although this strategy should reliably exclude false positive cases, sensitivity is undoubtedly less accurate.

\subsection{Conclusion}

Findings were largely congruent with previous studies emphasizing the damaging effects of adverse childhood experiences (Burgess et al., 1986; Hickey, 2002), but the present study advances understanding by beginning to fill the gaps between proposed theoretical models that have been suggested to apply only to sadistic sexual murderers (Marshall \& Kennedy, 2003), and those attempting to elucidate the processes that explain both sexual murder and non-homicide sexual aggression (Chan et al., 2011). That is, the present study offers empirical support for the relevance of deviant sexual fantasy in the case of sexual murder where killing and sex are directly linked, but the findings also help to establish the ways in which murder that is indirectly sexual and non-homicide sexual aggression may be predicted based on developmental, adult lifestyle, and criminal career factors. Taken together with additional research emerging in the field, the present findings will contribute to efforts to reach a multifactorial theoretical model of sexual homicide.

\section{Funding}

This research did not receive any specific grant from funding agencies in the public, commercial, or not-for-profit sectors.

\section{Acknowledgements}

The authors thank the Public Protection Unit, Her Majesty's Prison and Probation Service, UK for enabling access to the Public Protection 


\section{Unit Database.}

\section{References}

Ainsworth, M. D. S. (1979). Infant-mother attachment. American Psychologist, 34(10), 932-937.

Akers, R. L. (1985). Deviant behavior: A social learning approach (3rd ed.). Belmont, CA: Wadsworth.

American Psychiatric Association (2013). Diagnostic and statistical manual of mental disorders (5th ed.). Arlington, VA: American Psychiatric Association.

Andrews, D. A. (1995). The psychology of criminal conduct and effective treatment. In J. McGuire (Ed.). What works: Reducing reoffending - guidelines for research and practice (pp. 35-62). Chichester, UK: John Wiley \& Sons.

Arrigo, B. A., \& Purcell, C. E. (2001). Explaining paraphilias and lust murder: Toward an integrated model. International Journal of Offender Therapy and Comparative Criminology, 45(1), 6-31. http://dx.doi.org/10.1177/0306624x01451002.

Bandura, A. (1986). Social foundations of thought and action: A social cognitive theory Englewood Cliffs, NJ: Prentice Hall.

Beauregard, E., DeLisi, M., \& Hewitt, A. (2017). Sexual murderers: Sex offender, murderer, or both? Sexual Abuse, 1-19. http://dx.doi.org/10.1177/1079063217711446.

Beauregard, E., \& Martineau, M. (2013). A descriptive study of sexual homicide in Canada: Implications for police investigation. International Journal of Offender Therapy and Comparative Criminology, Vol. 57(12), 1454-1476.

Beauregard, E., \& Martineau, M. (2016). The sexual murderer: Offender behavior and implications for practice. Abingdon, UK: Routledge.

Beauregard, E., \& Mieczkowski, T. (2012). Risk estimations of the conjunction of victim and crime event characteristics on the lethal outcome of sexual assaults. Violence and Victims, 27(4), 470-486. http://dx.doi.org/10.1891/0886-6708.27.4.470.

Beauregard, E., \& Proulx, J. (2002). Profiles in the offending process of nonserial sexual murderers. International Journal of Offender Therapy and Comparative Criminology, 46(4), 386-399. http://dx.doi.org/10.1177/0306624X02464002.

Beauregard, E., \& Proulx, J. (2007). A classification of sexual homicide against men. International Journal of Offender Therapy and Comparative Criminology, 51(4), 420-432. http://dx.doi.org/10.1177/0306624x06294432.

Beech, A., Fisher, D., \& Ward, T. (2005). Sexual murderers' implicit theories. Journal of Interpersonal Violence, 20(11), 1366-1389. http://dx.doi.org/10.1177/ 0886260505278712.

Brittain, R. P. (1970). The sadistic murderer. Medicine, Science, and the Law, 10(4), 198-207.

Burgess, A. W., Hartman, C. R., Ressler, R. K., Douglas, J. E., \& McCormack, A. (1986). Sexual homicide: A motivational model. Journal of Interpersonal Violence, 1(3), 251-272.

Campos, E., \& Cusson, M. (2007). Serial killers and sexual murderers. In J. Proulx, E. Beauregard, M. Cusson, \& A. Nicole (Eds.). Sexual murderers: A comparative analysis and new perspectives (pp. 99-106). Chichester, UK: John Wiley \& Sons.

Carter, A. J., Hollin, C., Stefanska, E. B., Higgs, T., \& Bloomfield, S. (2016). The use of crime scene and demographic information in the identification of non-serial sexual homicide. International Journal of Offender Therapy and Comparative Criminology, 1-16. http://dx.doi.org/10.1177/0306624X16630313.

Carter, A. J., \& Hollin, C. R. (2014). Assessment and treatment when sex is attached to a killing: A case study. In D. T. Wilcox, T. G. Garrett, \& L. Harkins (Eds.). Sex offender treatment: A case study approach to issues and interventions (pp. 286-304). Chichester, UK: Wiley-Blackwell.

Carter, A. J., Mann, R. E., \& Wakeling, H. C. (2008). Sexual killers and post mortem sexual interference offenders: Assessment, treatment, and risk management. In A. J. R. Harris, \& C. A. Pagé (Eds.). Sexual homicide and paraphilias: The correctional service of Canada's experts forum 2007 (pp. 167-212). Ottawa, Ontario: Correctional Service of Canada.

Chan, H. C. O. (2015). Understanding sexual homicide offenders: An integrated approach. Hampshire, UK: Palgrave Macmillan.

Chan, H. C. O., \& Beauregard, E. (2016). Non-homicidal and homicidal sexual offenders: Prevalence of maladaptive personality traits and paraphilic behaviors. Journal of Interpersonal Violence, 31(13), 2259-2290. http://dx.doi.org/10.1177/ 0886260515575606.

Chan, H. C. O., \& Frei, A. (2013). Female sexual homicide offenders: An examination of an Underresearched offender population. Homicide Studies, 17(1), 96-118. http://dx.doi. org $/ 10.1177 / 1088767912449625$.

Chan, H. C. O., \& Heide, K. (2016). Sexual homicide offenders distinguished from nonhomicidal sexual offenders: A review of the literature. Aggression and Violent Behavior, 31, 147-156. http://dx.doi.org/10.1016/j.avb.2016.09.002.

Chan, H. C. O., \& Heide, K. M. (2009). Sexual homicide: A synthesis of the literature. Trauma, Violence \& Abuse, 10(1), 31-54. http://dx.doi.org/10.1177/ 1524838008326478.

Chan, H. C. O., Heide, K. M., \& Beauregard, E. (2011). What propels sexual murderers: A proposed integrated theory of social learning and routine activities theories. International Journal of Offender Therapy and Comparative Criminology, 55(2), 228-250.

Chan, H. C. O., Myers, W. C., \& Heide, K. M. (2010). An empirical analysis of 30 years of U.S. juvenile and adult sexual homicide offender data: Race and age differences in the victim-offender relationship. Journal of Forensic Sciences, 55(5), 1282-1290.

Clarke, J., \& Carter, A. J. (2000). Relapse prevention with sexual murderers. In D. R. Laws, S. M. Hudson, \& T. Ward (Eds.). Remaking relapse prevention with sex offenders: A sourcebook (pp. 389-401). Thousand Oaks, CA: Sage.

DeLisi, M. (2015). Mayhem by occupation: On the relevance of criminal careers to sexual homicide offenders. In A. Blokland, \& P. Lussier (Eds.). Sex offenders: A criminal career approach (pp. 219-230). Chichester, UK: John Wiley \& Sons.

Grubin, D. (1994). Sexual murder. British Journal of Psychiatry, 165, 624-629. http://dx. doi.org/10.1192/bjp.165.5.624.

Hare, R. D. (2004). The Hare psychopathy checklist - revised: Technical manual (2nd ed.). New York: Multi-Health Systems.

Harris, D. A., Knight, R. A., Smallbone, S., \& Dennison, S. (2011). Postrelease specialization and versatility in sexual offenders referred for civil commitment. Sexual Abuse, 23(2), 243-259. http://dx.doi.org/10.1177/1079063210384276.

Hart, S. D., Cox, D. N., \& Hare, R. D. (1995). Manual for the psychopathy checklist: Screening version (PCL: SV). Toronto: Multi-Health Systems.

Healey, J., \& Beauregard, E. (2015). The impact of persistent deviant sexual interests and persistent low self-esteem on sexual homicide. Criminal Justice and Behavior, 201, 1-18. http://dx.doi.org/10.1177/0093854815605874.

Healey, J., \& Beauregard, E. (2017). Impulsivity as an etiological factor in sexual homicide. Journal of Criminal Justice, 48, 30-36. http://dx.doi.org/10.1016/j.jcrimjus. 2016.12.002.

Hickey, E. W. (1997). Serial murderers and their victims (2nd ed.). Belmont, CA: Wadsworth.

Hickey, E. W. (2002). Serial murderers and their victims (3rd ed.). Belmont, CA: Wadsworth.

Higgs, T., Carter, A. J., Stefanska, E. B., \& Glorney, E. (2015). Toward identification of the sexual killer: A comparison of sexual killers engaging in post-mortem sexual interference and non-homicide sexual aggressors. Sexual Abuse. http://dx.doi.org/10. $1177 / 1079063215609935$.

Higgs, T., Carter, A. J., Tully, R. J., \& Browne, K. D. (2017). Sexual murder typologies: A systematic review. Aggression and Violent Behavior, 35, 1-12. http://dx.doi.org/10. 1016/j.avb.2017.05.004.

Higgs, T., Tully, R. J., \& Browne, K. D. (2017). Psychometric properties in forensic application of the screening version of the psychopathy checklist. International Journal of Offender Therapy and Comparative Criminology. http://dx.doi.org/10.1177/ $0306624 \mathrm{X} 17719289$.

Hill, A., Habermann, N., Klusmann, D., Berner, W., \& Briken, P. (2008). Criminal recidivism in sexual homicide perpetrators. International Journal of Offender Therapy and Comparative Criminology, 52(1), 5-20. http://dx.doi.org/10.1177/ $0306624 \times 07307450$.

Hill, A., Rettenberger, M., Habermann, N., Berner, W., Eher, R., \& Briken, P. (2012). The utility of risk assessment instruments for the prediction of recidivism in sexual homicide perpetrators. Journal of Interpersonal Violence, 27(18), 3553-3578. http://dx. doi.org/10.1177/0886260512447570.

Hosmer, D. W., \& Lemeshow, S. (2000). Applied logistic regression (2nd ed.). New York: John Wiley \& Sons.

James, J., \& Proulx, J. (2014). A psychological and developmental profile of sexual murderers: A systematic review. Aggression and Violent Behavior, 19(5), 592-607. http://dx.doi.org/10.1016/j.avb.2014.08.003.

James, J., \& Proulx, J. (2016). The modus operandi of serial and non-serial sexual murderers: A systematic review. Aggression and Violent Behavior, 31, 200-218. http://dx. doi.org/10.1016/j.avb.2016.09.006.

Kerr, K. J., Beech, A. R., \& Murphy, D. (2013). Sexual homicide: Definition, motivation and comparison with other forms of sexual offending. Aggression and Violent Behavior, 18(1), 1-10. http://dx.doi.org/10.1016/j.avb.2012.05.006.

Khachatryan, N., Heide, K. M., Hummel, E. V., \& Chan, H. C. O. (2016). Juvenile sexual homicide offenders: Thirty-year follow-up investigation. International Journal of Offender Therapy and Comparative Criminology, 60(3), 247-264. http://dx.doi.org/10. 1177/0306624X14552062.

Krafft-Ebing, R. (1886). In F. S. Klaf (Ed.). Psychopathia sexualisNew York: Arcade Trans.

Maniglio, R. (2010). The role of deviant sexual fantasy in the etiopathogenesis of sexual homicide: A systematic review. Aggression and Violent Behavior, 15(4), 294-302. http://dx.doi.org/10.1016/j.avb.2010.02.001.

Marshall, W. L., \& Kennedy, P. (2003). Sexual sadism in sexual offenders: An elusive diagnosis. Aggression and Violent Behavior, 8(1), 1-22. http://dx.doi.org/10.1016/ S1359-1789(01)00052-0.

Milsom, J., Beech, A. R., \& Webster, S. D. (2003). Emotional loneliness in sexual murderers: A qualitative analysis. Sexual Abuse, 15(4), 285-296. http://dx.doi.org/10. 1023/A:1025095927047.

Mokros, A., Osterheider, M., Hucker, S. J., \& Nitschke, J. (2011). Psychopathy and sexual sadism. Law and Human Behavior, 35(3), 188-199. http://dx.doi.org/10.1007/ s10979-010-9221-9.

Money, J. (1990). Forensic sexology: Paraphilic serial rape (biastophilia) and lust murder (erotophonophilia). American Journal of Psychotherapy, 44(1), 26-36.

Muthén, L. K., \& Muthén, B. O. (2007). MPlus user's guide (5th ed.). Los Angeles, CA: Authors.

Myers, W. C., Burgess, A. W., Burgess, A. G., \& Douglas, J. E. (1999). Serial murder and sexual homicide. In V. Van Hasselt, \& M. Hersen (Eds.). Handbook of psychological approaches with violent offenders (pp. 153-172). New York: Plenum.

Myers, W. C., \& Chan, H. C. O. (2012). Juvenile homosexual homicide. Behavioral Sciences \& the Law, 30(2), 90-102. http://dx.doi.org/10.1002/bsl.2000.

Nicole, A., \& Proulx, J. (2007). Sexual murderers and sexual aggressors: Developmental paths and criminal history. In J. Proulx, E. Beauregard, M. Cusson, \& A. Nicole (Eds.). Sexual murderers: A comparative analysis and new perspectives (pp. 29-50). Chichester, UK: John Wiley \& Sons.

Oliver, C. J., Beech, A. R., Fisher, D., \& Beckett, R. (2007). A comparison of rapists and sexual murderers on demographic and selected psychometric measures. International Journal of Offender Therapy and Comparative Criminology, 51(3), 298-312. http://dx. doi.org/10.1177/0306624x06289157.

Porter, S., Woodworth, M., Earle, J., Drugge, J., \& Boer, D. (2003). Characteristics of sexual homicides committed by psychopathic and non psychopathic offenders. Law 
and Human Behavior, 27(5), 459-470. http://dx.doi.org/10.1023/A:1025461421791.

Proulx, J. (2014). Pathways in the offending process of sexual aggressors: A research program. In J. Proulx, É. Beauregard, P. Lussier, \& B. Leclerc (Eds.). Pathways to sexual aggression (pp. 65-70). Oxon, UK: Routledge.

Proulx, J., \& Beauregard, E. (2009). Decision making during the offending process: An assessment among subtypes of sexual aggressors of women. In A. R. Beech, L. A. Craig, \& K. D. Browne (Eds.). Assessment and treatment of sex offenders: A handbook (pp. 181-198). Chichester, UK: John Wiley \& Sons.

Proulx, J., \& Beauregard, É. (2014). Pathways in the offending process of extrafamilial sexual aggressors against women. In J. Proulx, É. Beauregard, P. Lussier, \& B. Leclerc (Eds.). Pathways to sexual aggression (pp. 71-109). Oxon, UK: Routledge.

Proulx, J., Cusson, M., \& Beauregard, E. (2007). Sexual murder: Definitions, epidemiology and theories. In J. Proulx, E. Beauregard, M. Cusson, \& A. Nicole (Eds.). Sexual murderers: A comparative analysis and new perspectives (pp. 9-28). Chichester, UK: John Wiley \& Sons.

Ressler, R. K., Burgess, A. W., \& Douglas, J. E. (1988). Sexual homicide: Patterns and motives. New York: Free Press.

Revitch, E., \& Schlesinger, L. B. (1989). Sex murder and sex aggression: Phenomenology, psychopathology, psychodynamics and prognosis. Springfield, IL: Charles C. Thomas.

Rosman, J. P., \& Resnick, P. J. R. (1989). Sexual attraction to corpses: A psychiatric review of necrophilia. Bulletin of the Academy of Psychiatry and Law, 17(2), 153-163.

Salfati, C. G., \& Taylor, P. (2006). Differentiating sexual violence: A comparison of sexual homicide and rape. Psychology, Crime \& Law, 12(2), 107-125. http://dx.doi.org/10.
1080/10683160500036871.

Stefanska, E. B., Beech, A. R., \& Carter, A. J. (2016). A systematic review of the literature comparing male non-serial sexual killers and sexual aggressors: Examining homogenous and heterogenous characteristics of these groups. Journal of Sexual Aggression, 1-19. http://dx.doi.org/10.1080/13552600.2015.1126657.

Stefanska, E. B., Carter, A. J., Higgs, T., Bishopp, D., \& Beech, A. R. (2015). Offense pathways of non-serial sexual killers. Journal of Criminal Justice, 43(2), 99-107. http://dx.doi.org/10.1016/j.jcrimjus.2015.01.001.

Stein, M. L., Schlesinger, L. B., \& Pinizzotto, A. J. (2010). Necrophilia and sexual homicide. Journal of Forensic Sciences, 55(2), 443-446. http://dx.doi.org/10.1111/j.15564029.2009.01282.x

Tardif, M., Dassylva, B., \& Nicole, A. (2007). Psychotherapeutic and psychodynamic issues with sexual murderers. In J. Proulx, E. Beauregard, M. Cusson, \& A. Nicole (Eds.). Sexual murderers: A comparative analysis and new perspectives (pp. 213-228). Chichester, UK: John Wiley \& Sons.

Thornton, D. (2007). Scoring guide for risk matrix 2000.9/SVC. February 2007 Version. Retrieved from http://www.birmingham.ac.uk/Documents/college-les/psych/ RM2000scoringinstructions.pdf.

Vettor, S., Beech, A. R., \& Woodhams, J. (2014). Rapists and sexual murderers: Combined pathways to offending. In J. Proulx, E. Beauregard, P. Lussier, \& B. Leclerc (Eds.). Pathways to sexual aggression (pp. 285-315). Abingdon, UK: Routledge.

Ward, T., \& Beech, A. (2006). An integrated theory of sexual offending. Aggression and Violent Behavior, 11(1), 44-63. http://dx.doi.org/10.1016/j.avb.2005.05.002. 